\title{
Gray matter heterotopia: clinical and neuroimaging report on 22 children
}

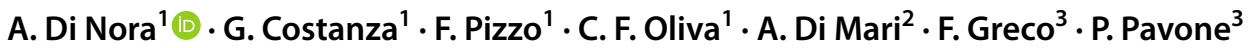

Received: 11 February 2021 / Accepted: 3 August 2021 / Published online: 1 September 2021

(c) The Author(s) 2021

\begin{abstract}
Objective To investigate the clinical characteristics and neuroimaging features of childhood presenting with gray matter heterotopia observed in a single tertiary Pediatric Department in Catania and compare the data with those reported in the literature.

Methods A retrospectively review of the history, clinical findings, electrophysiological features and magnetic resonance images of 22 children presenting with gray matter heterotopia observed from January 2010 to January 2020.

Results Among the 22 children included in the study, 17 presented with periventricular heterotopia (PVNH), two with Subcortical Band Heterotopia (SBH), and three with other subcortical heterotopia (SUBH). In the affected children, the ages at first diagnosis ranged from 3 months to 16 years with a mean age of 8.2 years $( \pm 5.4)$; twelve $(54.5 \%)$ suffered by developmental delay and intellectual deficit; eleven children (50\%) complained of epileptic seizures, mostly focal to bilateral tonic-clonic seizure. In addition, in the periventricular heterotopia group (PVNH), cerebral and systemic malformations were reported in twelve (70\%) and in ten (58\%) children, respectively, out of seventeen. In the SBH plus SUBH group, epileptic seizures were recorded in $3(60 \%)$ out of 5 children, cerebral malformations in one child and systemic malformations in two children. Conclusions Heterotopic gray matter malformations include a group of disorders that manifest with a variety of neurological implications, such as cognitive impairment and epilepsy, and often related with epilepsy, other cerebral malformations and systemic anomalies.
\end{abstract}

Keywords Heterotopia $\cdot$ Childhood $\cdot$ Clinical $\cdot$ Neuroimaging $\cdot$ Epilepsy

\section{Introduction}

Heterotopic gray matter malformations (HET) are clusters of normal neurons in abnormal locations, mainly due to impaired migration from approximately the 6th to 16th weeks of gestation [1-3]. The increasing availability and resolution of MRI technology and molecular genetics has resulted in a classification published by Barkovich et al. in the 2012 describing different types of malformations

A. Di Nora

alessandradinora@gmail.com

1 Department of Clinical and Experimental Medicine, University of Catania, Via S. Sofia 78, 95123 Catania, Italy

2 Department of Radiology, University of Catania, Catania, Italy

3 Department of Clinical and Experimental Medicine, Section of Pediatrics and Child Neuropsychiatry, Hospital "Policlinico G. Rodolico", Catania, Italy of cortical development (MCD) [4]. In 2019, Oegema et al. reviewed this classification [5]. In particular, he distinguished five groups and subdivided them into specific entities. Subcortical Heterotopic gray matter heterotopy (SUBH) was included in Groups 1, 2, 4 and 5, differently periventricular nodular heterotopia $(\mathrm{PVNH})$ and Subcortical Band Heterotopia (SBH) in group 3. In particular, Group 1 includes congenital microcephaly with premigrational reduced proliferation and variable additional $\mathrm{MCD}$; group 2 includes multifocal or focal cortical and subcortical dysgenesis; group 3 includes malformations due to abnormal neuronal migration, PVNH and SBH [6-10]; group 4 includes malformations due to abnormal postmigrational development with subcortical or transmantle components; and group 5 includes heterotopic gray matter brain malformations with bilateral complex patterns.

The diagnosis of GMH requires highly specialized and multidisciplinary expertise. Clinically, it has been commonly related to developmental delay and other systemic 
malformations. The purpose of this study was to evaluate the clinical and neuroimaging features of gray matter heterotopia observed over a 10 -year period in a single tertiary pediatric department to improve the clinicians' and radiologists' understanding of the disease.

\section{Methods}

We reviewed retrospectively the clinical records of the 22 children presenting with epilepsy and/or development delay and diagnosed at Brain MRI with HET, admitted at single tertiary Pediatric Department at the "Policlinico G. Rodolico" University-Hospital, Catania, Italy from January 2010 to January 2020. In this study, children were grouped according to the main types of heterotopia: seventeen had PVNH (77\%), three SBH (13\%), and two SUBH (9\%). The study was approved by the ethic Committee of the University Hospital of Catania University. We collected the data from the medical charts: sex, age at first diagnosis, seizure types, electroencephalograpic (EEG) results, neuropsychiatric evaluation, were reported together with other possible cerebral or systemic malformations presented by the children. Brain MRI studies included T1-weighted, T2-weighted, fluid-attenuated inversion recovery, diffusion-weighted and post-contrast T1 imaging. EEG was carried out for each child using the international 10-20 system.

\section{Results}

The age at first diagnosis ranged from 3 months to 16 years with a mean age of 8.2 years $( \pm 5.4)$. Twelve children were males $(54.6 \%)$ and ten (45.4\%) were females. The results obtained are distinguished on the basis of the type of HET and beneath reported:

\section{Periventricular nodular heterotopia (PVNH)}

This group of children includes nine females (52.9\%) and eight males (47.1\%), with mean age of establishing a diagnosis of 8.1 years $( \pm 6.1)$. This group of children includes nine females (52\%) and eight males (47\%), with mean age of the first diagnosis of 8 years $( \pm 6)$.

Table 1 shows the clinical features. Figure 1 shows the main characteristics and intensity of periventricular nodules on MRI.

\section{Subcortical band heterotopia (SBH)}

This group includes two children, one female and one male, with mean age of establishing a diagnosis of 7.5 years $( \pm 5.5)$. Table 2 shows clinical features.

\section{Subcortical heterotopia (SUBH)}

This group includes three children, all males, with mean age of establishing a diagnosis of 9 years $( \pm 1.8)$. Table 3 shows the clinical features. Figure 2 shows the main characteristics and intensity of periventricular nodules on MRI.

\section{Discussion}

In this retrospective review, we selected 22 children affected by HET: 17 presenting with PVNH 2 with SBH, and 3 with SUBH. HET manifests with variable clinical expression, mainly presenting with DD/ID, epilepsy and other brain and systemic malformations [3, 9-12]. In this series, 12 out of $22(54 \%)$ subjects showed delayed cognitive function, and 11 out of 22 subjects $(50 \%)$ showed epilepsy with a lower frequency than the results from other studies that reported cognitive disability and epilepsy in a greater number of cases $[11,12]$.

In literature HET is associated with epilepsy [13-15]; about this, in our experience 11/22 patients (50\%) developed epilepsy. Several studies reported that periventricular heterotopia is the type of GMH more associated with the epilepsy $(80-90 \%)[12,16]$, which was more common focal seizure than general $[12,13]$, and more detected in females than males $[4,15]$. Differently, in our periventricular group we detected epilepsy in 8/17 patients (47\%), with a female predominance (female to male ratio 5:3). About the type of epilepsy, we found generalized seizures in $4 / 8$ patients, followed by two patients with infantile spasms and two with focal seizure. In the report of Srour et al., all patients with infantile spasms showed bilateral lesions [16]: in our case series, only $1 / 2$ with infantile spasms showed bilateral lesions in accordance with the study of Hung et al. [11]. Consistent with the literature, the most common EEG abnormality was focal epileptiform.

About the subcortical group, we collected three patients affected by epilepsy, two focal type and one generalized seizures, and no other anomalies. Only one patient had strabismus. Raza et al. report a study with ten patients affected by subcortical heterotopia [17]: they describe an association with subcortical heterotopia, central nervous system (CNS) anomalies and neurological dysfunction. Probably due to the low number of patients, we did not detect these findings.

About the band group, we collected two patients with psychomotor delay, without seizures. One of the two patients had hemispheric cystic. Hung et al. describe 10 patients with band heterotopia [11], associating it with 
Table 1 Data of 17 patients with periventricular heterotopia

\begin{tabular}{|c|c|c|c|c|c|c|c|c|}
\hline ID patient & $\begin{array}{l}\text { Patient sex age } \\
\text { at the diagnosis }\end{array}$ & Seizure & Seizure types & EEG & $\begin{array}{l}\text { Heterotopic } \\
\text { localisation }\end{array}$ & Outcome & $\begin{array}{l}\text { Other CNS malfor- } \\
\text { mations }\end{array}$ & $\begin{array}{l}\text { Systemic malforma- } \\
\text { tions/manifestations }\end{array}$ \\
\hline ID-101 & $\begin{array}{l}\text { Female } \\
10.75 \mathrm{y}\end{array}$ & Yes & FS & Left FE & Unilateral & Delayed & No & No \\
\hline ID-102 & $\begin{array}{l}\text { Male } \\
13.3 \mathrm{y}\end{array}$ & Yes & $\mathrm{F}$ to Bil & Right FE & Unilateral & Normal & No & No \\
\hline ID-103 & $\begin{array}{l}\text { Female } \\
8.3 \mathrm{y}\end{array}$ & No & & Normal & Bilateral & Delayed & $\begin{array}{l}\text { VM } \\
\text { Hemispheric cyst } \\
\text { AVM } \\
\text { PVL } \\
\text { Polymicrogyria } \\
\text { CVH }\end{array}$ & $\begin{array}{l}\text { Skeletal Dysplasia } \\
\text { Ostium secundum } \\
\text { atrial septal defect }\end{array}$ \\
\hline ID-104 & $\begin{array}{l}\text { Female } \\
0.25 \mathrm{y}\end{array}$ & Yes & IS & Multifocal FE & Unilateral & Normal & $\begin{array}{l}\text { ACC } \\
\text { Aicardi Syndrome }\end{array}$ & No \\
\hline ID-105 & $\begin{array}{l}\text { Female } \\
0.75 \mathrm{y}\end{array}$ & Yes & IS & GE & Bilateral & Normal & $\mathrm{VM}$ & $\begin{array}{l}\text { Congenital Hyper- } \\
\text { trophic cardiomyo- } \\
\text { pathy }\end{array}$ \\
\hline ID-106 & $\begin{array}{l}\text { Male } \\
4.25 \mathrm{y}\end{array}$ & Yes & GS & Multifocal FE & Bilateral & Delayed & $\begin{array}{l}\text { VM } \\
\text { Microcephaly } \\
\text { Polymicrogyria }\end{array}$ & No \\
\hline ID-107 & $\begin{array}{l}\text { Male } \\
3 \mathrm{y}\end{array}$ & Yes & GS & Normal & Unilateral & Delayed & No & $\begin{array}{l}\text { Classical Ehlerse- } \\
\text { Danlos syndrome } \\
\text { (COL5A1) }\end{array}$ \\
\hline ID-108 & $\begin{array}{l}\text { Female } \\
1.6 \mathrm{y}\end{array}$ & No & & Normal & Bilateral & Normal & $\begin{array}{l}\text { VM } \\
\text { ACC } \\
\text { CVH } \\
\text { Dandye-Walker cyst }\end{array}$ & Strabismus \\
\hline ID-109 & $\begin{array}{l}\text { Male } \\
2 y\end{array}$ & No & & Normal & Bilateral & Delayed & VM & $\begin{array}{l}\text { Skeletal dysplasia } \\
\text { Strabismus }\end{array}$ \\
\hline ID-110 & $\begin{array}{l}\text { Female } \\
0.8 \mathrm{y}\end{array}$ & No & & Normal & Unilateral & Delayed & No & No \\
\hline ID-111 & $\begin{array}{l}\text { Female } \\
15 \mathrm{y}\end{array}$ & Yes & $\mathrm{F}$ to bil & Right FE & Bilateral & Normal & No & GH deficiency \\
\hline ID-112 & $\begin{array}{l}\text { Male } \\
12.3 \mathrm{y}\end{array}$ & No & & Normal & Unilateral & Delayed & $\begin{array}{l}\mathrm{VM} \\
\mathrm{ACC}\end{array}$ & $\begin{array}{l}\text { Hypertelorism } \\
\text { Nystagmus } \\
\text { Conjunctival hyper- } \\
\text { trophy }\end{array}$ \\
\hline ID-113 & $\begin{array}{l}\text { Male } \\
14 \mathrm{y}\end{array}$ & No & & Normal & Bilateral & Delayed & VM & Papillary edema \\
\hline ID-114 & $\begin{array}{l}\text { Male } \\
2 \mathrm{y}\end{array}$ & No & & Normal & Bilateral & Normal & Hemispheric cyst & $\begin{array}{l}\text { Cortical cysts in the } \\
\text { right kidney }\end{array}$ \\
\hline ID-115 & $\begin{array}{l}\text { Female } \\
12 \mathrm{y}\end{array}$ & No & & Normal & Unilateral & $\begin{array}{l}\text { Enuresis } \\
\text { Encopresis }\end{array}$ & $\begin{array}{l}\text { Spinal Dysraphism } \\
\text { with meningocele } \\
\text { and tethered cord }\end{array}$ & No \\
\hline ID-116 & $\begin{array}{l}\text { Female } \\
16.4 \mathrm{y}\end{array}$ & Yes & FS & GE & Unilateral & Normal & $\mathrm{VM}$ & $\begin{array}{l}\text { Bicuspid aortic valve } \\
\text { GH deficiency }\end{array}$ \\
\hline ID-117 & $\begin{array}{l}\text { Male } \\
15 \mathrm{y}\end{array}$ & No & & Normal & Bilateral & Delayed & $\begin{array}{l}\text { Ectopic neurohypo- } \\
\text { physis }\end{array}$ & No \\
\hline
\end{tabular}

$A C C$ agenesis of corpus callosum, $A V M$ arteriovenous malformation, $C H D$ congenital heart disease, $C V H$ cerebellar vermis hypoplasia, $F E$ focal epileptiform, $F S$ focal seizure, $F$ to Bil Focal to Bilateral tonic-clonic seizures, $Y$ years, $P V L$ periventricular leukomalacia, $V M$ ventriculomegaly, $G E$ generalized epileptiform, $G H$ growth hormone, $G S$ generalized seizure, $I B D$ inflammatory Bowel Disease, $I S$ infantile spasms

brain anomalies and congenital malformations. As the precedent group, due to the low number of patients, it is difficult compare our results.
HET can be associated with other CNS anomalies: in our case series, especially in periventricular group, we noted the recurrence of ventriculomegaly (8/17) in accordance with 

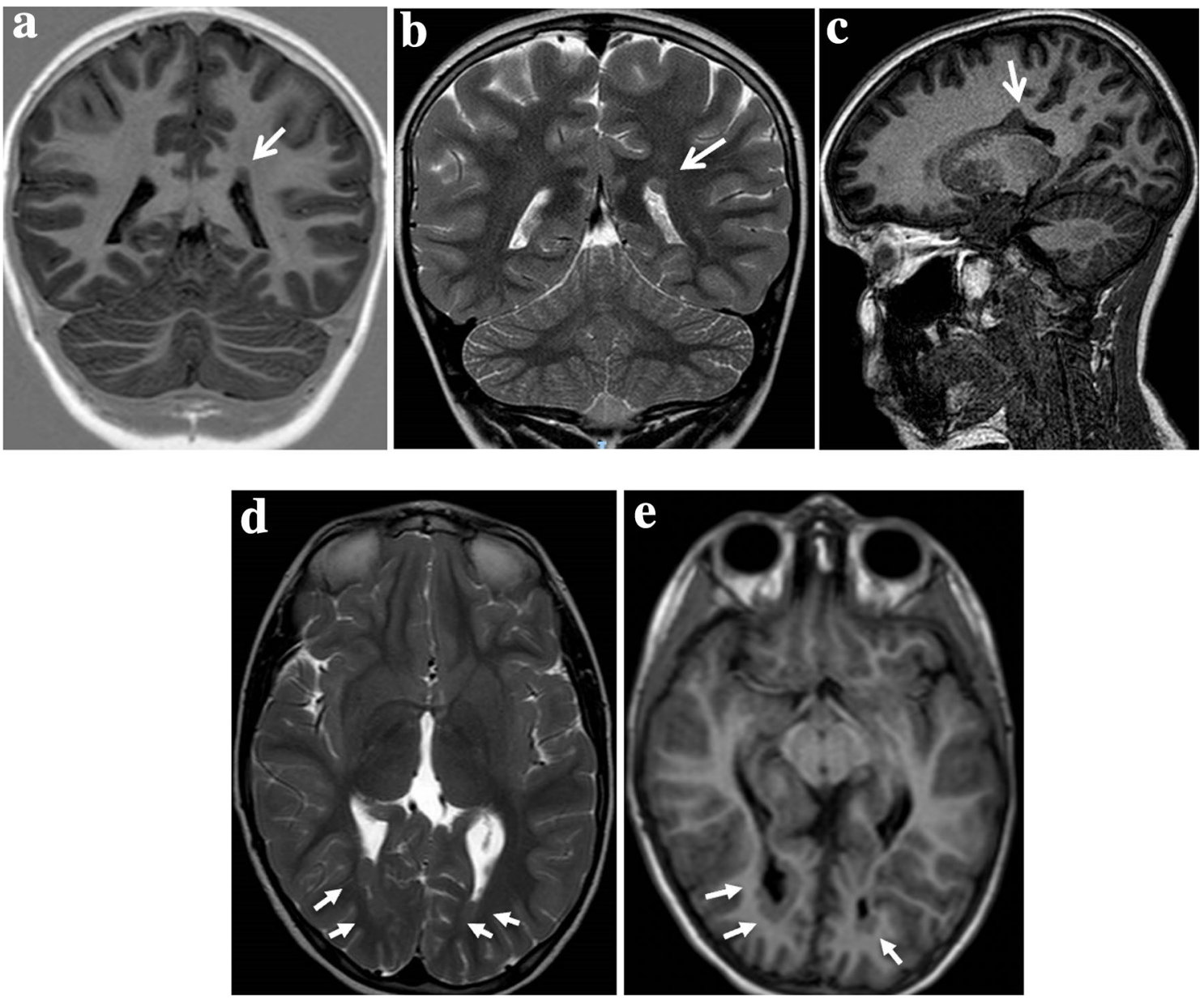

Fig. 1 Periventricular nodular heterotopia $(P V N H)$. a, b, c Unilateral $P V N H$ (ID 101): Unenhanced magnetic resonance imaging coronal a and mid sagittal c T1-weighted and coronal T2-weighted b shows a small unilateral periventricular nodule, isointense to the gray matter, along the left lateral ventricular wall (arrows) with indentation of the ventricular profile (arrow). d, e Bilateral PVNH (ID103) Unenhanced T2-weighted $\mathbf{d}$ and T1-weighted e magnetic resonance axial images shows a few nodules that are lining ventricular occipital horns bilaterally (arrows)

Table 2 Data of two children with SBH

\begin{tabular}{|c|c|c|c|c|c|c|c|c|}
\hline ID patient & $\begin{array}{l}\text { Patient sex age } \\
\text { at the diagnosis }\end{array}$ & Seizure & Seizure types & EEG & $\begin{array}{l}\text { Heterotopic } \\
\text { Localisa- } \\
\text { tion }\end{array}$ & $\begin{array}{l}\text { Psychomotor } \\
\text { development }\end{array}$ & $\begin{array}{l}\text { Other CNS malfor- } \\
\text { mations }\end{array}$ & $\begin{array}{l}\text { Systemic malforma- } \\
\text { tions/manifestations }\end{array}$ \\
\hline ID-201 & $\begin{array}{l}\text { Female } \\
11.3 \mathrm{y}\end{array}$ & No & & Normal & Bilateral & Delayed & Hemispheric cyst & No \\
\hline ID-202 & $\begin{array}{l}\text { Male } \\
3.8 \mathrm{y}\end{array}$ & No & & Multifocal S-W & Unilateral & Delayed & No & $\begin{array}{l}\text { Bicuspid aortic valve } \\
\text { Nystagmus }\end{array}$ \\
\hline
\end{tabular}

$S$ - $W$ Spikes-Wave

the literature (Fig. 3). In contrast to the paper Hung et al. and Srour et al. [11, 16], we found that bilateral heterotopia are more likely have ventriculomegaly instead of unilateral type. Ventriculomegaly is followed by agenesis of corpus callosum (3/17), cerebellar vermis hypoplasia (Fig. 4a) (2/17) and polymicrogyria (2/17) (Fig. 4b, c). In addition, we found in 2/17 hemispheric cyst (Fig. 5a, b).
In accordance with the data of Hung et al., we report the case of a patient with Dandy-Walker cyst and the case of a patient with Ehlers-Danlos syndrome. Advances in genetic show a correlation between connective tissue disorder and periventricular heterotopia [18]: our experience confirms this date. 
Table 3 Data of three probands with subcortical heterotopia (SUBH)

\begin{tabular}{lllllllll}
\hline ID patient & $\begin{array}{l}\text { Patient sex and age } \\
\text { at the diagnosis }\end{array}$ & Seizure & $\begin{array}{l}\text { Seizure tupes } \\
\text { types }\end{array}$ & EEG & $\begin{array}{l}\text { Heterotopic } \\
\text { Localisation }\end{array}$ & $\begin{array}{l}\text { Psychomotor Other CNS } \\
\text { development } \\
\text { manlformations }\end{array}$ & $\begin{array}{l}\text { Systemic } \\
\text { malforma- } \\
\text { tions }\end{array}$ \\
\hline ID-301 & $\begin{array}{l}\text { Male } \\
8.5 \mathrm{y}\end{array}$ & Yes & FS & F. S-W Right & Nodular & Normal & No \\
ID-302 & $\begin{array}{l}\text { Male } \\
7.5 \mathrm{y} \\
\text { Male }\end{array}$ & Yes & F to Bil & F to Bil & Nodular & Normal & No & No \\
ID-303 & Yes & FS & Normal & Nodular & Normal & No \\
\hline
\end{tabular}

FS focal seizures, $F$ to Bil focal to bilateral tonic-clonic seizures, $F$. $S$-W frontal spike and wave frontal
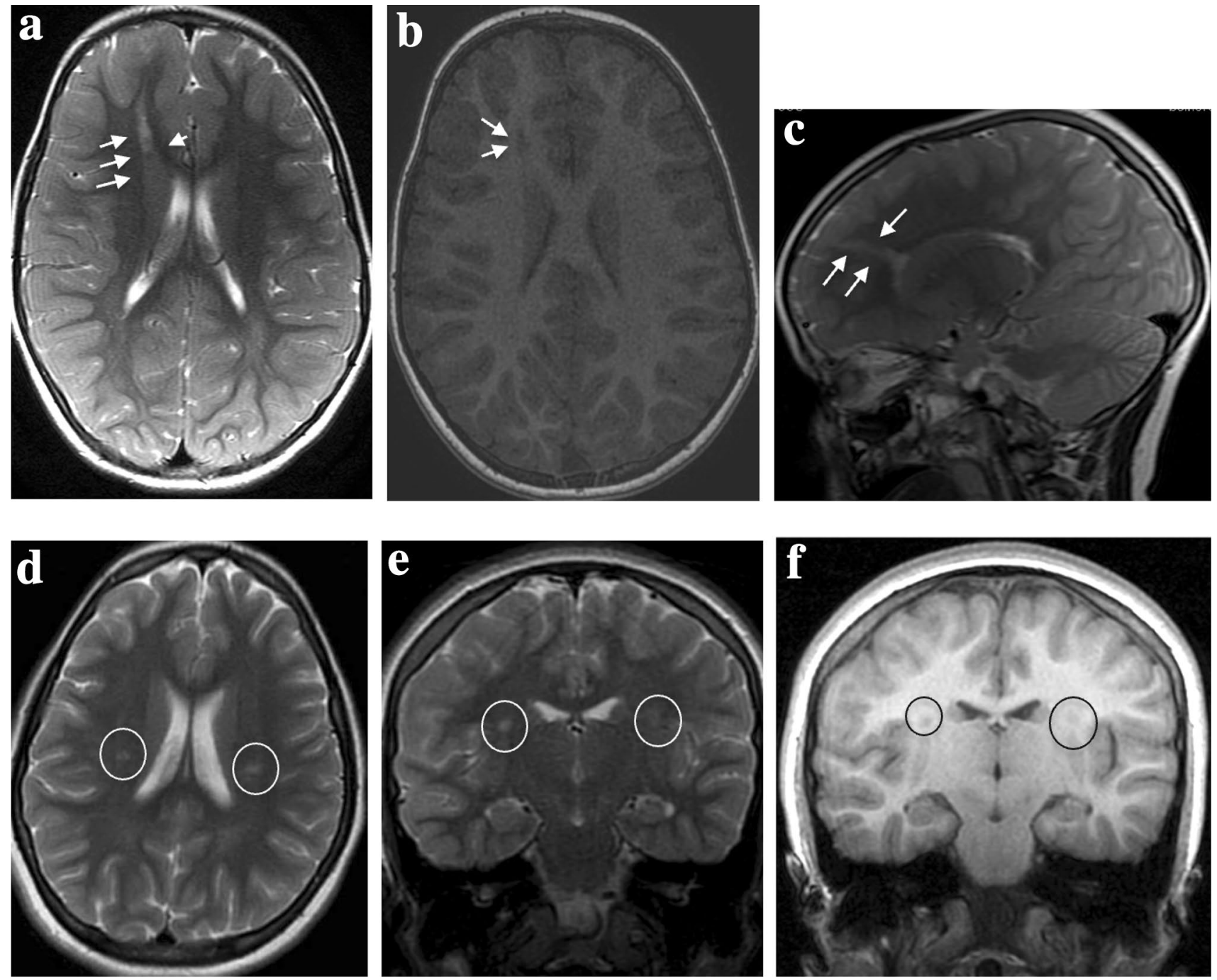

Fig. 2 Subcortical heterotopia (SUBH). a-c (ID 302) Non-contrast enhancement magnetic resonance imaging, Axial T2- weighted image (a) and T1-weighted image (b) and mid-sagittal T2-weighted image show mantle stripe, isointense to the cerebral cortex with a serpiginous pattern, which stretches in oblique cranio-caudal direction from the right frontal cortico-subcortical region to the anterior horn of the homolateral lateral ventricle (arrows), compatible with sub-cortical heterotopia. d-f (ID 303) Non-contrast enhancement magnetic resonance imaging axial $\mathbf{d}$ and coronal $\mathbf{e}$ T2-weighted image and coronal T1-weighted image $\mathbf{f}$ shows a bilateral nodule of SNH (circles), isointense to gray matter 

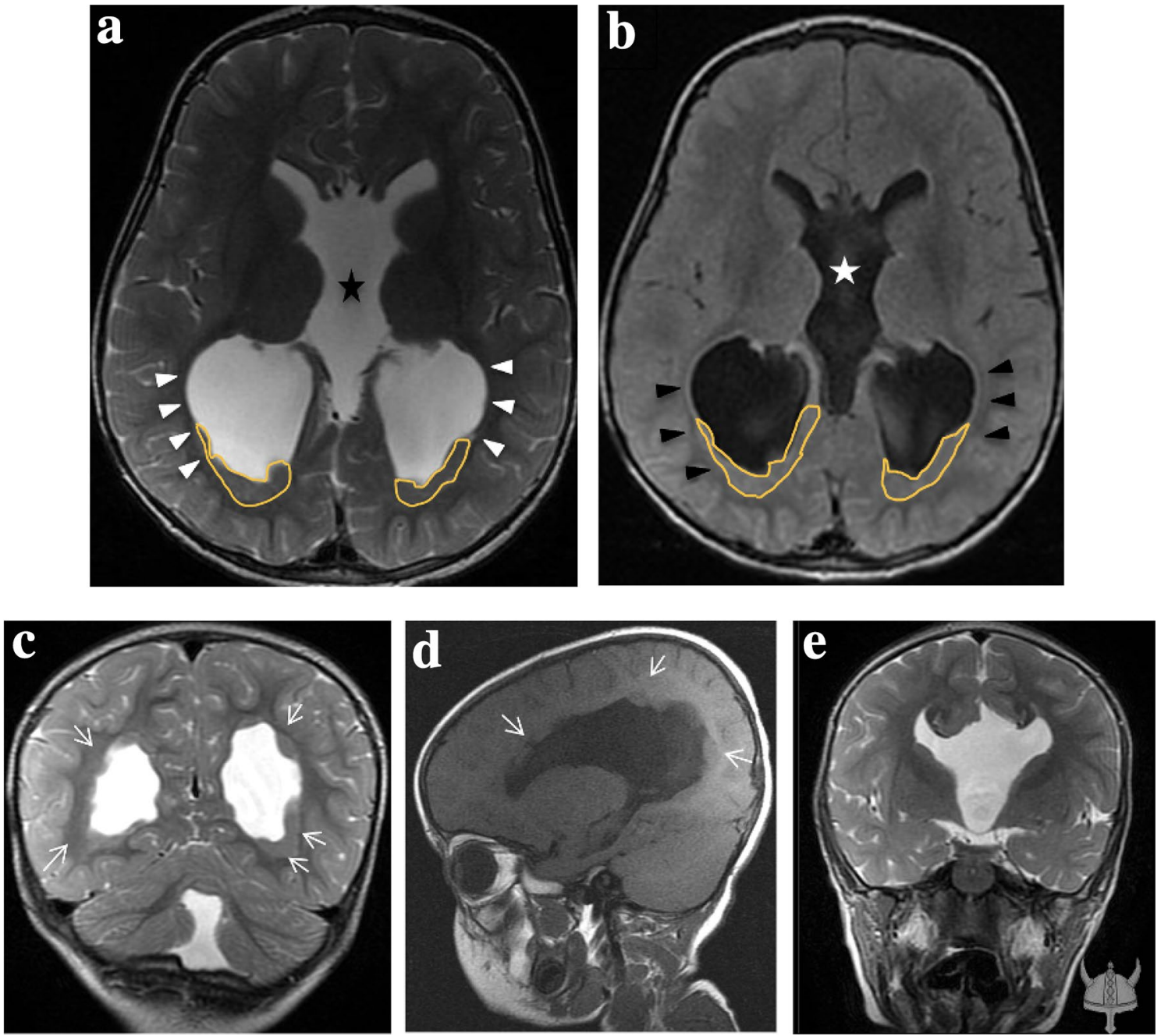

Fig. 3 (ID 108): Agenesis of the corpus callosum and cavum septum pellicidum, ventriculomegaly and cerebellar vermis atrophy in patient with bilateral periventricular nodular heterotopia $(P V N H)$. a, b Non-contrast enhancement axial T2-weighted MR image a and T1-weighted MR image b shows enlargement of the ventricles in particular the images show dilatation of the third ventricle (star) and lateral ventricles with widely spaced parallel bodies (arrowheads) in patient with bilateral periventricular nodular heterotopia (white lines). c Unenhanced T2-weighted MR coronal image show bilateral perive-

Interestingly, we report the case of a patient with periventricular heterotopia and Aicardi syndrome, showing seizures and agenesis of corpus callosum, typical features described in the syndrome [19].

About the other systemic malformations, our experience shows a correlation between heterotopia and cardiac diseases, previously described by other studies $[11,16]$. Also, we found ocular abnormalities, especially strabismus, in $6 / 22$ patients. Interestingly, we found two patients with growth hormone deficiency $(\mathrm{GH})$ and heterotopia. We attribute this incidence in our case series, never described before, because our center is a reference department of ntricular nodular heterotopia (PVNH) (arrows), enlarged lateral ventricles and cerebellar vermis atrophy. d Unenhanced T1-weighted MR midsagittal image show dysmorphic ventricular system and periventricular nodular heterotopia (arrows). e T2 -weighted MR coronal image shows the "Viking helmet appearance" refers to the morphology of the lateral ventricles in the coronal plane in patients with dysgenesis of the corpus callosum. The cingulate gyrus is everted into narrowed and elongated frontal horns

endocrinology and neurology pediatric. In these patients MRI did not show pituitary lesions, so they received diagnosis of GH deficiency idiopathic. In literature, growth hormone deficiency and heterotopia are rarely correlated, such as Vilboux et al. in a Joubert patient [20]. Mitchell et al. reported a study with a possible correlation between periventricular heterotopia, ectopic posterior pituitary lobe and GH deficiency [21]. In our case series, one patient had ectopic posterior pituitary lobe and periventricular heterotopia (Fig. 6); differently, in two patients with GH deficiency MRI did not show anomalies to the posterior pituitary. 

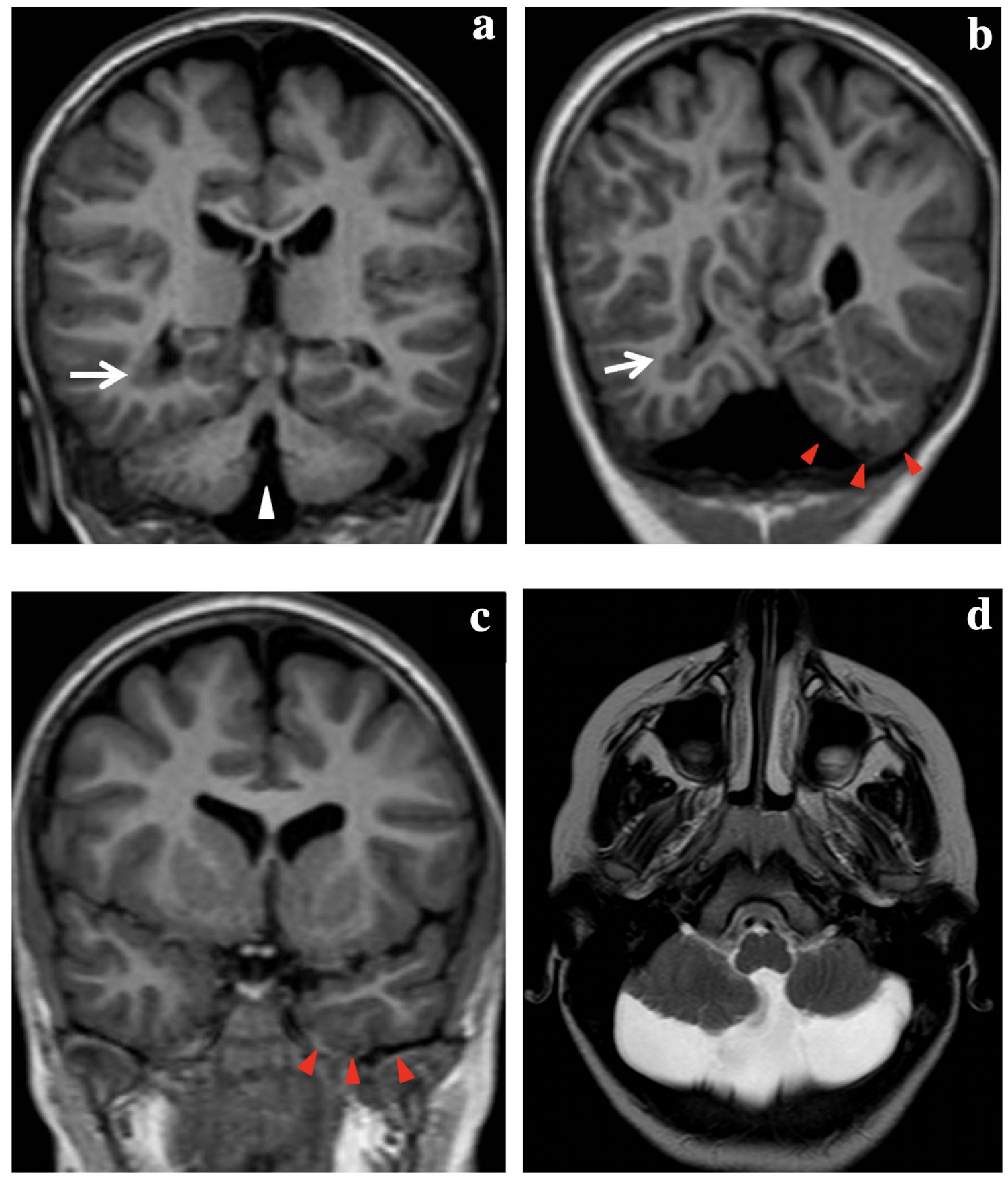

Fig. 4 (ID 103) Brain malformations associated with monolateral periventricular heterotopia $(P V N H)$ a, b T1-weighted coronal MR images demonstrates nodular periventricular heterotopia (white arrows) in the right lateral ventricle, cerebellar vermis hypoplasia a

Our study had some limitations. The study population was small, especially for the subcortical and band group. All the data were obtained retrospectively. Our patients were only from a single tertiary hospital in Catania. In addition, genetic testing was not performed in our cohort. (white arrowhead) b, c T1-weighted coronal MR images shows pachygyric appearance of the left parahippocampal gyrus with a 'nubby' appearance to the cortical surface (white arrows) d T2-weighted assial MR image show cerebellar hemisphere and vermis hypoplasia

Our report confirms that heterotopia may be a clue of different and various cerebral and systemic anomalies; for this reason, in case of GMHs for the clinicians it's important value the cardiac function, ocular abnormalities and eventually skeletal or renal anomalies. 

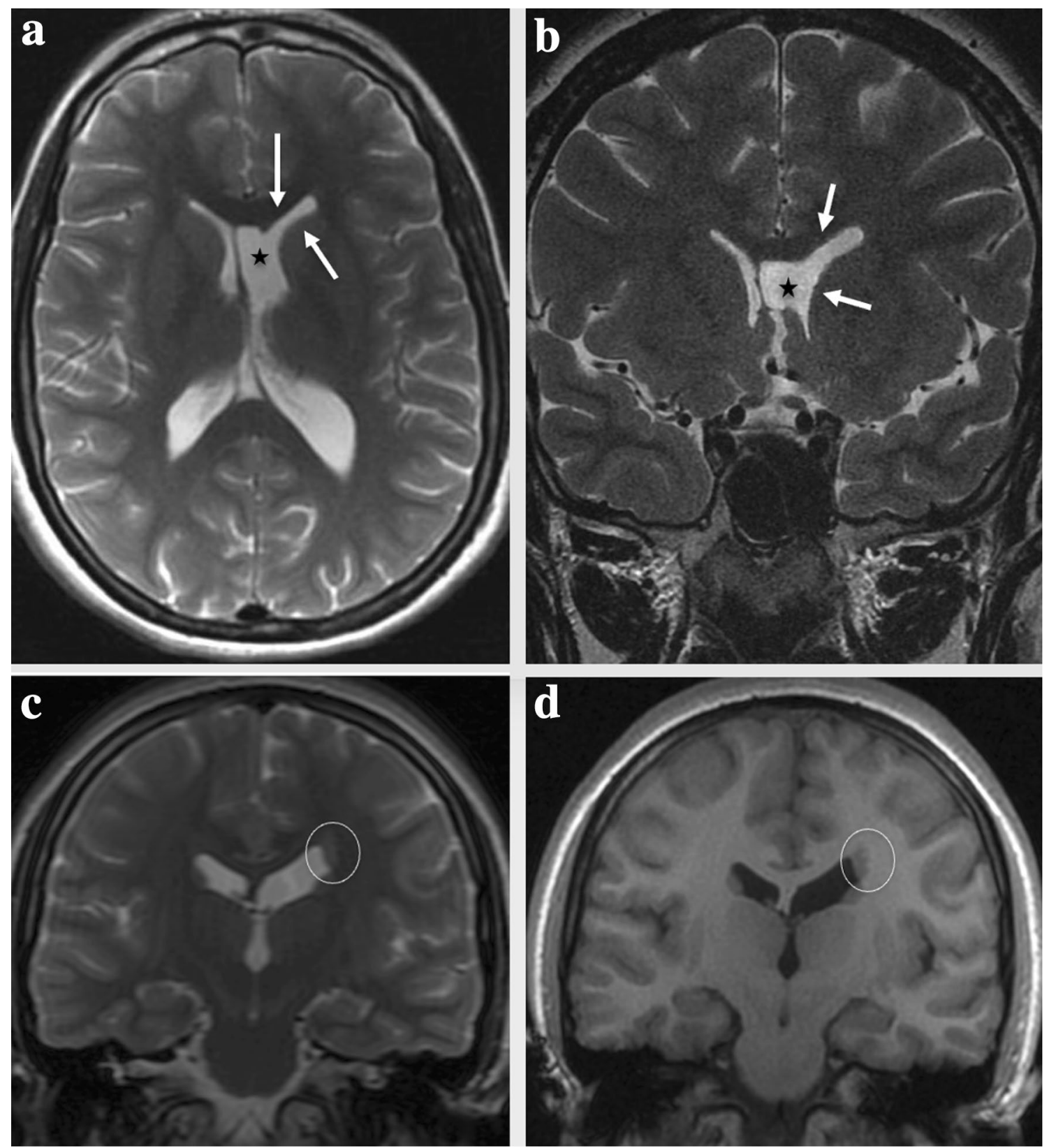

Fig. 5 (ID 109): Dysmorphic left lateral ventricles and periventricular nodular heterotopia $(P V N H)$. a, b Unenhanced axial T2-weighted (T2w) magnetic resonance image a and unenhanced coronal T2-weighted (T2w) magnetic resonance image b shows dysmorphic left lateral ventricles (white arrows) that appear fused with cyst of

the cavum septum pellucidum (black star). c, d Coronal T2-weighted (T2w) magnetic resonance image $\mathbf{c}$ and T1 3D FSPGR (fast spoiled gradient echo) coronal magnetic resonance image d shows periventricular nodular heterotopia (white circle) 


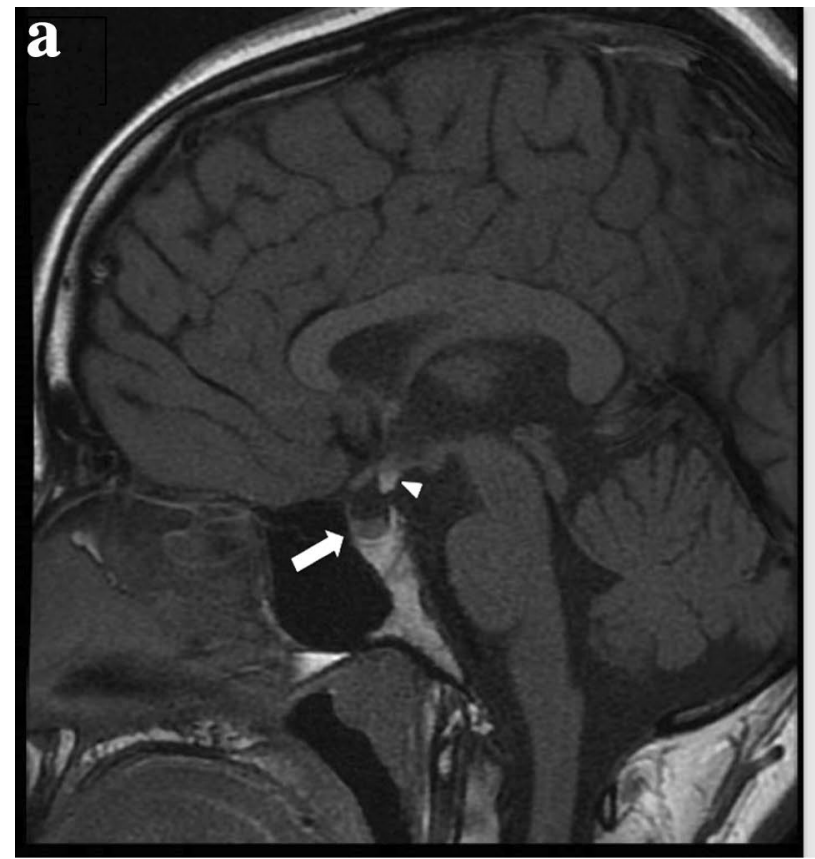

Fig. 6 (ID 109): Ectopic posterior pituitary lobe. a, b Unenhanced T1-weighted (T1w) midsagittal and coronal magnetic resonance images shows hyperintensity at the median eminence, which corresponds to ectopic posterior pituitary lobe (arrowheads). Anterior

Acknowledgements The authors also wish to thank American Manuscript Editors for reviewing the manuscript and Springer Editing Sevices (certification number 57FB-A1FD-91C5-F26C-2A7F) for reviewing the manuscript.

Author contributions All the authors have equally contributed to the writing of the manuscript and critically revised it for intellectual content.

Funding Open access funding provided by Università degli Studi di Catania within the CRUI-CARE Agreement.

\section{Declarations}

Conflict of interest All authors declare do not have conflict of interests.

Data availability The data used to support the findings of this study may be released upon application to the corresponding author, who can be contacted at alessandradinora@gmail.com.

Ethical approval The study was conducted ethically in accordance with the World Medical Association's Declaration of Helsinki.

Informed consent Informed consent was obtained from the parents/or caregivers of the probands.

Open Access This article is licensed under a Creative Commons Attribution 4.0 International License, which permits use, sharing, adaptation, distribution and reproduction in any medium or format, as long as you give appropriate credit to the original author(s) and the source, provide a link to the Creative Commons licence, and indicate if changes

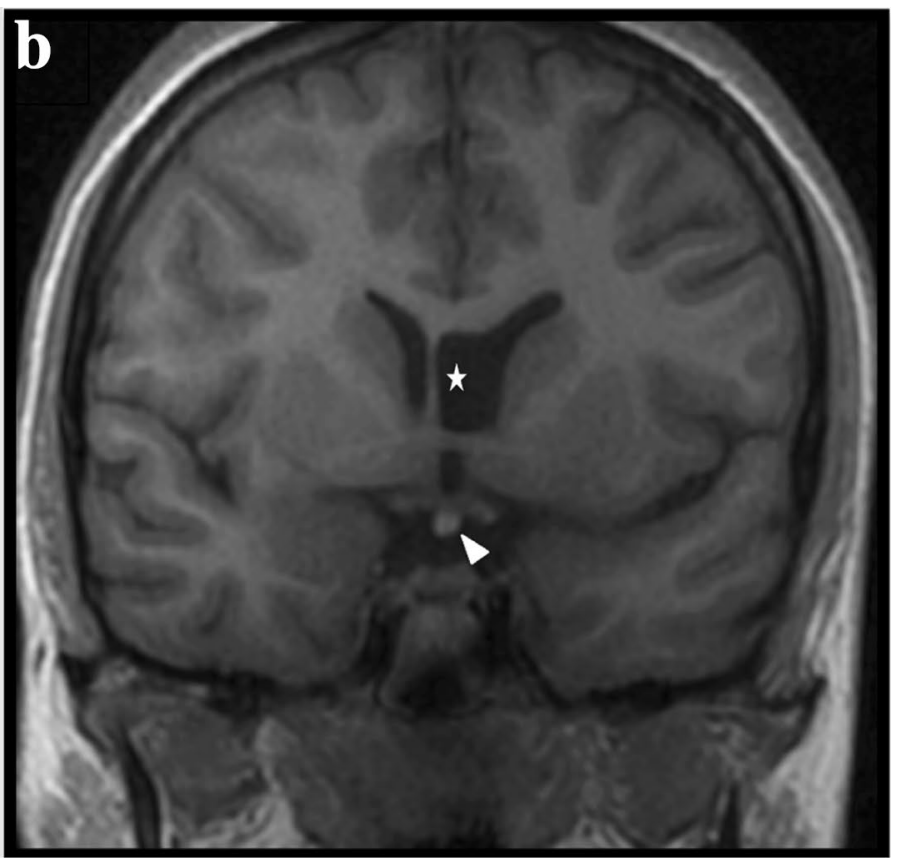

pituitary lobe appears normally localized although small and flattened (arrow). b Dysmorphic left lateral ventricles that appear fused with cyst of the cavum septum pellucidum (white star)

were made. The images or other third party material in this article are included in the article's Creative Commons licence, unless indicated otherwise in a credit line to the material. If material is not included in the article's Creative Commons licence and your intended use is not permitted by statutory regulation or exceeds the permitted use, you will need to obtain permission directly from the copyright holder. To view a copy of this licence, visit http://creativecommons.org/licenses/by/4.0/.

\section{References}

1. Barkovich AJ, Kuzniecky RI (2000) Gray matter heterotopia. Neurology 55(11):1603-1608

2. Barkovich AJ, Guerrini R, Kuzniecky RI, Jackson GD, Dobyns WB (2012) A developmental and genetic classification for malformations of cortical development: update. Brain 135:1348-1369

3. Aronica E, Mühlebner A (2017) Neuropathology of epilepsy. Handb Clin Neurol 145:193-216

4. Barkovich AJ, Kjos BO (1992) Gray matter heterotopia: MR characteristics and correlation with developmental and neurologic manifestations. Radiology 182:493-499

5. Oegema R, Barkovich AJ, Mancini GMS, Guerrini R, Dobyns WB (2019) Subcortical heterotopic gray matter brain malformations: classification study of 107 individuals. Neurology 93(14):e1360-e1373

6. Barkovich AJ (2000) Morphological characteristics of subcortical heterotopia: MR imaging study. Am J Neuroradiol 21(2):290-295

7. Donkol RH, Moghazy KM, Abolenin A (2012) Assessment of gray matter heterotopia by magnetic resonance imaging. World $\mathrm{J}$ Radiol 4(3):90-96 
8. Pavone L, Corsello G, Pavone P, Iannetti P (2010) Lissencephalic syndromes: brain and beyond. Front Biosci (Sch Ed) 2:85-95

9. DeMyer W (1986) Megalencephaly: types, clinical syndromes, and management. Pediatr Neurol 2:321-328

10. Jansen PR, Dremmen M, van den Berg A, Dekkers IA, Blanken LME, Muetzel RL et al (2017) Incidental findings on brain imaging in the general pediatric population. N Engl J Med 377(16):1593-1595

11. Hung PC, Wang HS, Chou ML, Lin KL, Hsieh MY, Wong AM (2016) Clinical and neuroimaging findings in children with gray matter heterotopia: a single institution experience of 36 patients. Eur J Paediatr Neurol 20(5):732-737

12. Dubeau F, Tampieri D, Lee N, Andermann E, Carpenter S, Leblanc R et al (1995) Periventricular and subcortical nodular heterotopia. A study of 33 patients. Brain 118(Pt 5):1273-1287

13. Battaglia G, Chiapparini L, Franceschetti S, Freri E, Tassi L, Bassanini S et al (2006) Periventricular nodular heterotopia: classification, epileptic history, and genesis of epileptic discharges. Epilepsia 47(1):86-97

14. Barkovich AJ (1996) Subcortical heterotopia: a distinct clinicoradiologic entity. AJNR Am J Neuroradiol 17(7):1315-1322

15. Aghakhani Y, Kinay D, Gotman J, Soualmi L, Andermann F, Olivier A et al (2005) The role of periventricular nodular heterotopia in epileptogenesis. Brain 128(Pt 3):641-651
16. Srour M, Rioux MF, Varga C, Lortie A, Major P, Robitaille $Y$ et al (2011) The clinical spectrum of nodular heterotopia in children: report of 31 patients. Epilepsia 52(4):728-737

17. Raza HK, Chen H, Chansysouphanthong T, Zhang Z, Hua F, Ye X et al (2019) The clinical and imaging features of gray matter heterotopia: a clinical analysis on 15 patients. Neurol Sci 40(3):489-494

18. Sheen VL, Walsh CA (2005) Periventricular heterotopia: new insights into Ehlers-Danlos syndrome. Clin Med Res 3(4):229-233

19. Hopkins B, Sutton VR, Lewis RA, Van den Veyver I, Clark G (2008) Neuroimaging aspects of Aicardi syndrome. Am J Med Genet A 146A(22):2871-2878

20. Vilboux T, Malicdan MC, Roney JC, Cullinane AR, Stephen J, Yildirimli D et al (2017) CELSR2, encoding a planar cell polarity protein, is a putative gene in Joubert syndrome with cortical heterotopia, microophthalmia, and growth hormone deficiency. Am J Med Genet A 173(3):661-666

21. Mitchell LA, Thomas PQ, Zacharin MR, Scheffer IE (2002) Ectopic posterior pituitary lobe and periventricular heterotopia: cerebral malformations with the same underlying mechanism? AJNR Am J Neuroradiol 23(9):1475-1481

Publisher's Note Springer Nature remains neutral with regard to jurisdictional claims in published maps and institutional affiliations. 